\title{
Verification of the effect of sleeping environment and humidification on middle-aged people in whole-house air-conditioning ventilation system housing
}

\author{
Akemi Iwaki $^{1, *}$, Takashi Akimoto ${ }^{2}$, Naho Misumi ${ }^{3}$, and Takuya Furuhashi ${ }^{3}$ \\ ${ }^{1}$ Shibaura Institute of Technology, SIT Research Laboratories, 3-7-5 Toyosu, Koto, Tokyo 135-8548, Japan \\ ${ }^{2}$ Shibaura Institute of Technology, Dept. of Architecture, 3-7-5 Toyosu, Koto, Tokyo 135-8548, Japan \\ ${ }^{3}$ Mitsubishi Electric Corporation, Living Environment Systems Laboratory, Kamakura, Kanagawa 247-8501, Japan
}

\begin{abstract}
This study focused on the thermal comfort of air circulation-type whole-house airconditioning ventilation systems. We studied the influence of 24-h continuous whole-house airconditioning on the living environment in which the occupant is sleeping. A survey was conducted in the summer of 2016 and winter of 2017 to ascertain the influence on the sleeping environment, skin moisture content, and blood pressure. We then compared the results with those of the sleeping environment of residents in air-conditioned housing surveyed the previous year. The sleeping environment when using a personal humidifier around the occupant's head was examined during winter when the humidity is low. The results indicated that sleep latency was significantly shortened in the 24-h continuous whole-house air-conditioning ventilation system in both summer and winter because the temperature control of the bedroom before going to bed affects the sleep latency. Subjectively, no participants felt dryer than the values measured in the bedroom environment. The results implied that the comfort of the entire building was improved with continuous air-conditioned housing.
\end{abstract}

\section{Introduction}

The recent years have seen a strong demand for energy saving and low carbonization of houses; therefore, highly airtight and insulated houses are actively being promoted.

In Japan, a whole-house duct-type air-conditioned housing that integrates ventilation and air conditioning is drawing attention as the next-generation system for enhancing thermal comfort in the living environment and promoting good health. This research focuses on the thermal comfort of the air-circulation-type whole-house air-conditioning. We also explore the manner in which the thermal environment of 24-h continuous air conditioning affects the living environment of the house and, in particular, how it influences sleep patterns. The study participants are middle-aged people. The factors considered are the sleeping environment, effects on skin moisture content during summer and winter, and changes in blood pressure. These results are compared with those of individual residential air conditioners in FY 2015 [1]. In winter, when the humidity is likely to be low, verification is performed for the case when a personal humidifier is used around the occupant's head.

\section{Methods}

\subsection{Experimental participants}

Table 1 shows the outline of the experiment in the whole-house air-conditioning ventilation system housing. Table 2 presents the measurement items. Table 3 shows the average value of the personal attribute of the participants. A total of 11 participants were involved: four males and two females in summer and four males and one female in winter. Their ages ranged from the late $30 \mathrm{~s}$ to $50 \mathrm{~s}$, and they had no health abnormalities. The average age (SD: standard deviation) was 49.5 (4.8) and 50.2 (4.9) years for the summer and winter experiments, respectively. The average BMI was 22.6 (1.7) $\mathrm{kg} / \mathrm{m}^{2}$ and $22.5(2.0) \mathrm{kg} / \mathrm{m}^{2}$ for the summer and winter experiments, respectively. The participants were encouraged to maintain their regular daily living routines during the examination period. In addition, we banned them from performing intensive exercises, consuming alcohol, and sunbathing. The nature of the research was explained to the participants both verbally and in writing. Moreover, a written consent was obtained from all the participants. Informed consent was obtained from each participant in accordance with the Declaration of Helsinki (Seoul Revision, 2008) and the General Data

\footnotetext{
* Corresponding author: na14904@shibaura-it.ac.jp
} 
Table 1. Outline of the experiment in the whole-house air-conditioning ventilation system housing.

\begin{tabular}{|c|c|c|c|}
\hline Experiment location & \multicolumn{3}{|c|}{ Whole-house air-conditioning ventilation system housing / participant's bedroom } \\
\hline Measurement duration & $\begin{array}{c}\text { Summer: } \\
\text { September 5-September 12, } \\
2016 \text { (conditions: } 7 \text { days) }\end{array}$ & $\begin{array}{r}\text { February } 5-1 \\
\text { (7 days for each conc }\end{array}$ & $\begin{array}{l}\text { Iary } 27,2017 \\
\text { for a total of } 14 \text { days) }\end{array}$ \\
\hline $\begin{array}{c}\text { Temperature and humidity } \\
\text { condition }\end{array}$ & \multicolumn{3}{|c|}{ Continuous measurement by thermorecorder } \\
\hline Air-conditioning condition & \multicolumn{3}{|c|}{ Continue to use for $24 \mathrm{~h}$, declare settings } \\
\hline Experimental condition & $\begin{array}{l}\text { Summer: } \\
24 \mathrm{~h} \text { continuous operation }\end{array}$ & $\begin{array}{c}\text { Winter } \\
\text { (first half): } \\
24 \mathrm{~h} \text { continuous operation }\end{array}$ & $\begin{array}{c}\text { Winter } \\
\text { (second half): } \\
24 \mathrm{~h} \text { continuous operation } \\
+ \text { humidifier }\end{array}$ \\
\hline Participant & $\begin{array}{l}\text { Summer: } 6 \text { middle-aged } \\
\text { males and females } \\
(38 \text { to } 58 \text { years old })\end{array}$ & \multicolumn{2}{|c|}{$\begin{array}{l}\text { Winter: } 5 \text { middle-aged } \\
\text { males and females } \\
\text { (43 to } 58 \text { years old) } \\
\end{array}$} \\
\hline
\end{tabular}

Table 2. Measurement items.

\begin{tabular}{|c|c|c|c|c|}
\hline \multicolumn{2}{|c|}{ Measurement item } & Measuring device & Number of measurements & position \\
\hline \multirow{3}{*}{$\begin{array}{l}\text { Physiological } \\
\text { quantity }\end{array}$} & $\begin{array}{l}\text { Skin moisture } \\
\text { content }\end{array}$ & $\begin{array}{l}\text { Skin moisture meter } \\
\text { MY-808S/scala }\end{array}$ & $\begin{array}{l}\text { Before bedtime/ } \\
\text { after getting up/every day }\end{array}$ & $\begin{array}{l}\text { Cheek middle: } \\
\text { Fig. 1(D) }\end{array}$ \\
\hline & Blood pressure & $\begin{array}{l}\text { Blood pressure monitor } \\
\text { HEM-7132/OMRON }\end{array}$ & $\begin{array}{l}\text { Before bedtime/ } \\
\text { after getting up/every day }\end{array}$ & $\begin{array}{l}\text { Upper arm: } \\
\text { Fig. } 1(\mathrm{E})\end{array}$ \\
\hline & Sleep & $\begin{array}{l}\text { Mat-type sleep measuring } \\
\text { device } \\
\text { SL-501/TANITA }\end{array}$ & $\begin{array}{l}\text { Before bedtime/ } \\
\text { after getting up/every day }\end{array}$ & Fig. 1(C) \\
\hline $\begin{array}{l}\text { Psychological } \\
\text { quantity }\end{array}$ & $\begin{array}{l}\text { Sense of } \\
\text { dryness and } \\
\text { airflow } \\
\text { Hot/humidity/ } \\
\text { comfortable } \\
\text { feeling, } \\
\text { etc. }\end{array}$ & & $\begin{array}{l}\text { Before bedtime/ } \\
\text { after getting up/every day }\end{array}$ & \\
\hline Environment & $\begin{array}{l}\text { Temperature/ } \\
\text { humidity }\end{array}$ & $\begin{array}{l}\text { Thermorecorder } \\
\text { TR-72Ui/T\&D }\end{array}$ & $\begin{array}{l}\text { Experiment period/ } \\
14 \text { days }\end{array}$ & $\begin{array}{l}\text { In the bedroom/the } \\
\text { head of the bed: Fig } \\
1(\mathrm{~A}) / \text { in the bed }\end{array}$ \\
\hline
\end{tabular}

Protection Regulation (GDPR) prior to performing the experiments.

\subsection{Experiment duration and location}

The measurements were recorded in the summer of 2016 and winter of 2017, each over 14 days in the bedroom of the house of a participant in the suburbs of Tokyo. All of the participants' residences are a wooden detached house with a 24-h continuous whole-house air-conditioning ventilation system.

\subsection{Experimental conditions}

Two conditions were set for the winter experiment: with and without a humidifier.

Under the humidifier condition, the participants were asked to use a personal humidifier for seven days in the second half of the experiment. The humidification system of personal humidifiers was of the steam, boiling-water, and releasing-steam type (SH-KX1-W; Mitsubishi Electric Corporation) and used only around the head of the participants for localized humidifying. The participant recorded his/her daily air-conditioning temperature setting in the bedroom in the questionnaire. The participant's clothing and bedding specifications were also indicated on the questionnaire.
For sleep evaluation, a "Sleep Health Risk Index" (SHRI) [2] was used as a questionnaire to evaluate the comprehensive sleep health in daily life in addition to a mat-type sleep-measuring device [3]. In the questionnaire, the following factors were studied: sleep patterns, lifestyle, health condition, and bedroom environment. The clothes and bedding of the participants were also noted in the questionnaire.

\subsection{Measurement procedure}

In addition to the physiological volume measurement, we measured air temperature and humidity around the head during sleep to comprehend the bedroom environment during the experiment. A strong relationship is believed to exist between air temperature and humidity in the bedroom and sleep patterns [4-6]. Figure 1 shows the measurement position in the participants' bedroom. The participants measured their

Table 3. Personal attribute average value (SD).

\begin{tabular}{c||c|c|c|c}
\hline & $\begin{array}{c}\text { Average } \\
\text { age [years] }\end{array}$ & $\begin{array}{c}\text { Height } \\
{[\mathrm{cm}]}\end{array}$ & $\begin{array}{c}\text { Weight } \\
{[\mathrm{kg}]}\end{array}$ & $\begin{array}{c}\mathrm{BMI} \\
{\left[\mathrm{kg} / \mathrm{m}^{2}\right]}\end{array}$ \\
\hline $\begin{array}{c}\text { Summer } \\
(\mathrm{n}=6)\end{array}$ & 49.0 & 166.3 & 61.5 & 22.6 \\
$(4.7)$ & $(11.8)$ & $(9.8)$ & $(1.7)$ \\
\hline Winter & 50.2 & 169.2 & 64.6 & 22.5 \\
$(\mathrm{n}=5)$ & $(4.9)$ & $(10.7)$ & $(9.4)$ & $(2.4)$ \\
\hline
\end{tabular}




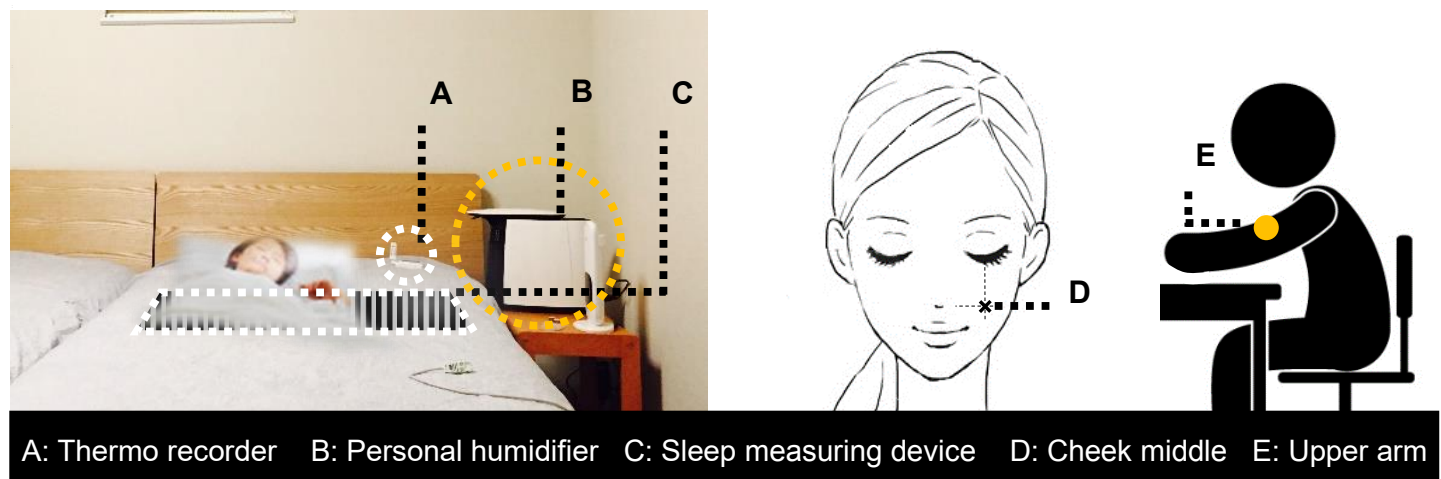

Fig. 1. Measurement position of the participant's bedroom and on the skin.

skin moisture content and blood pressure while at rest and reported psychological quantities. The skin moisture content was measured thrice at the center of the cheek. The blood pressure was measured twice on the upper part of the left arm. The numerical values were recorded in the web questionnaire. The participants switched on the humidifier (winter only) and the sleep measuring device at bedtime. After waking up, they again completed all measurements and the web questionnaire.

\section{Results}

Analysis of the data used five days of experiment except two days before among the seven days experiment.

\subsection{Sleep Health Risk Index questionnaire}

The degree of risk to sleep health was obtained using the SHRI as a subjective indicator. The SHRI comprises five factors: sleep maintenance disorder, sleep attendant symptom, sleep apnea, difficulty in wakening, and sleep onset disorder. The standard value is 50 . The higher the numerical value, the poorer the sleep health. The sleep maintenance impairment was significantly high at $68.0 \pm$ 11.6 in both summer and winter, suggesting that middleaged people have difficulty maintaining sleep.

\subsection{Questionnaire on the bedroom environment}

Figure 2 shows the summary results of the bedroom environment in summer and winter. The level of thermal comfort of the whole-house air-conditioning ventilation system was very high during both seasons.

\subsection{Questionnaire on air-conditioning during sleep}

Figure 3 illustrates the declaration result when the whole-house air-conditioning ventilation system is used in summer and winter. The declaration showed that the airflow in the summer season was practically not felt and did not matter at all in winter.

A slight dryness was felt in winter when using the whole-house air-conditioning ventilation system, but the effect was felt when one has allergy to pollen.

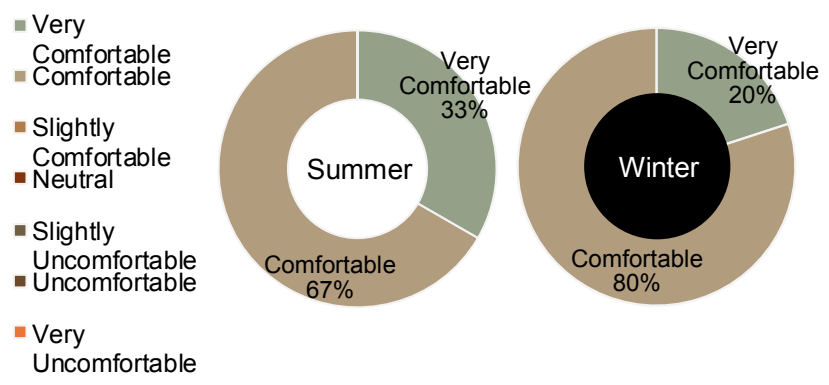

Fig. 2. Thermal comfortable feeling of the bedroom at the whole-house air-conditioning ventilation system housing.

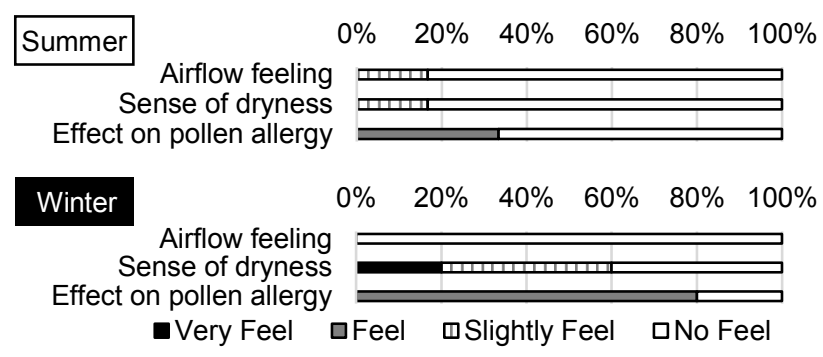

Fig. 3. Declaration result at the time of using the wholehouse air-conditioning ventilation system.

Table 4. Average temperature and humidity during bedtime (SD).

\begin{tabular}{c|c|c} 
Environment & Condition (h: humidifier) & Measurements \\
\cline { 2 - 3 } $\begin{array}{c}\text { Bedroom } \\
\text { temperature } \\
{\left[{ }^{\circ} \mathrm{C}\right]}\end{array}$ & Summer whac & $26.3(1.2)$ \\
\cline { 2 - 3 } & Winter whac & $21.4(1.6)$ \\
\cline { 2 - 3 } $\begin{array}{c}\text { Bedroom } \\
\text { humidity } \\
{[\% \mathrm{RH}]}\end{array}$ & Winter whac $+\mathrm{h}$ & $21.5(1.7)$ \\
\cline { 2 - 3 } & Summer whac & $54.9(8.1)$ \\
\cline { 2 - 3 } & Winter whac & $28.1(9.6)$ \\
\cline { 2 - 3 } $\begin{array}{c}\text { Around the head } \\
\text { temperature } \\
{\left[{ }^{\circ} \mathrm{C}\right]}\end{array}$ & Winter whac $+\mathrm{h}$ & $35.0(5.9)$ \\
\cline { 2 - 3 } & Summer whac & $26.2(1.1)$ \\
\cline { 2 - 3 } & Winter whac & $20.4(2.6)$ \\
\hline \multirow{2}{*}{$\begin{array}{c}\text { Around the head } \\
\text { relative humidity } \\
{[\% \mathrm{RH}]}\end{array}$} & Winter whac $+\mathrm{h}$ & $20.9(2.0)$ \\
\cline { 2 - 3 } & Summer whac & $54.3(7.5)$ \\
\cline { 2 - 3 } & Winter whac & $28.0(11.5)$ \\
\hline \multirow{2}{*}{$\begin{array}{c}\text { Around the head } \\
\text { absolute humidity } \\
{[\mathrm{g} / \mathrm{kg}]}\end{array}$} & Winter whac $+\mathrm{h}$ & $36.9(5.5)$ \\
\cline { 2 - 3 } & Summer whac & $13.3(1.7)$ \\
\cline { 2 - 3 } & Winter whac & $4.7(1.5)$ \\
\hline
\end{tabular}

whac: whole-house air-conditioning 


\subsection{Temperature and humidity environment of the bedroom}

Table 4 presents the measurement results of the bedroom environment in summer and winter. They were cast in terms of the bedroom air temperature and relative humidity, air temperature and relative humidity around the head, and the average value (SD) of the absolute humidity around the head. During winter, the lowest recorded relative humidity around the head was 28.0 (11.5) \% RH when the system was in use, and the drying was conspicuous. The air temperature in the bedroom at bedtime was approximately $20{ }^{\circ} \mathrm{C}$ under both conditions.

\subsection{Sleep}

Table 5 shows the average value from the sleepmeasuring device. The measurement results using the mat-type sleep-measuring device implied that the sleeping efficiency did not decrease in the summer season, and no seasonal difference was detected. This
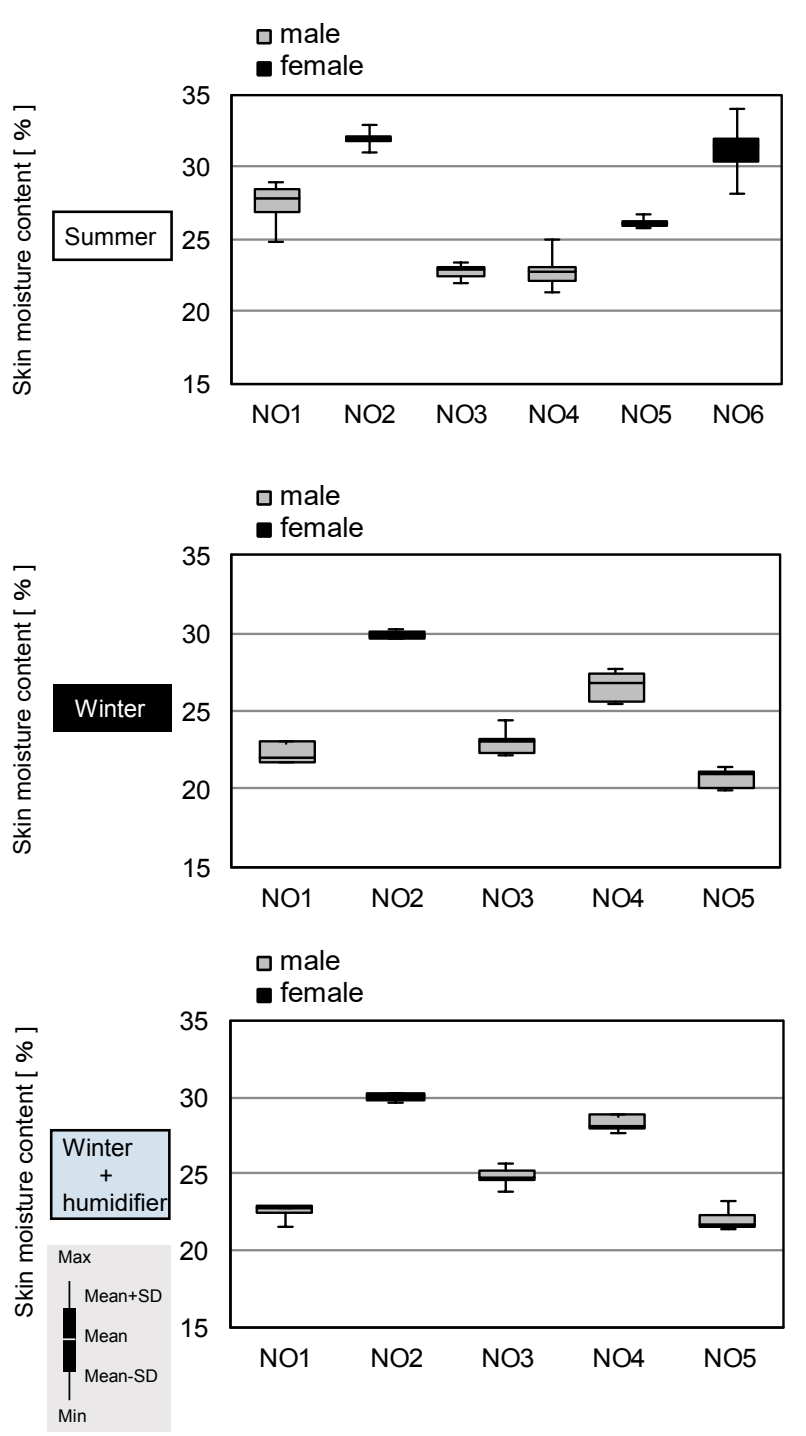

Fig. 4. Average value of the skin moisture content for each condition after getting up.
Table 5. Average sleep measurement result of the wholehouse air-conditioning ventilation system housing.

\begin{tabular}{c|c|c|c|c|c|c}
\hline \multirow{2}{*}{} & \multicolumn{2}{|c|}{ Summer } & \multicolumn{2}{c|}{ Winter } & \multicolumn{2}{c}{$\begin{array}{c}\text { Winter } \\
\text { + humidifier }\end{array}$} \\
\cline { 2 - 7 } & Avg & SD & Avg & SD & Avg & SD \\
\hline $\begin{array}{c}\text { Actual } \\
\text { sleeping } \\
\text { time [min] }\end{array}$ & 305.4 & 70.5 & 295.2 & 85.0 & 288.7 & 96.8 \\
\hline $\begin{array}{c}\text { Sleeping } \\
\text { efficiency } \\
\text { [\%] }\end{array}$ & 86.6 & 3.9 & 86.4 & 3.3 & 86.6 & 3.4 \\
\hline $\begin{array}{c}\text { Deep sleep } \\
\text { appearance } \\
\text { rate [\%] }\end{array}$ & 13.8 & 8.3 & 15.7 & 6.7 & 15.2 & 8.5 \\
\hline $\begin{array}{c}\text { Deep sleep } \\
\text { ratio first } \\
\text { half [\%] }\end{array}$ & 51.4 & 28.1 & 50.8 & 27.7 & 59.2 & 28.8 \\
\hline $\begin{array}{c}\text { Sleep } \\
\text { latency } \\
\text { [min] }\end{array}$ & 4.6 & 5.0 & 4.5 & 4.4 & 4.3 & 3.3 \\
\hline $\begin{array}{c}\text { Awake } \\
\text { appearance } \\
\text { rate [\%] }\end{array}$ & 13.5 & 3.9 & 13.5 & 3.3 & 13.3 & 3.3 \\
\hline
\end{tabular}
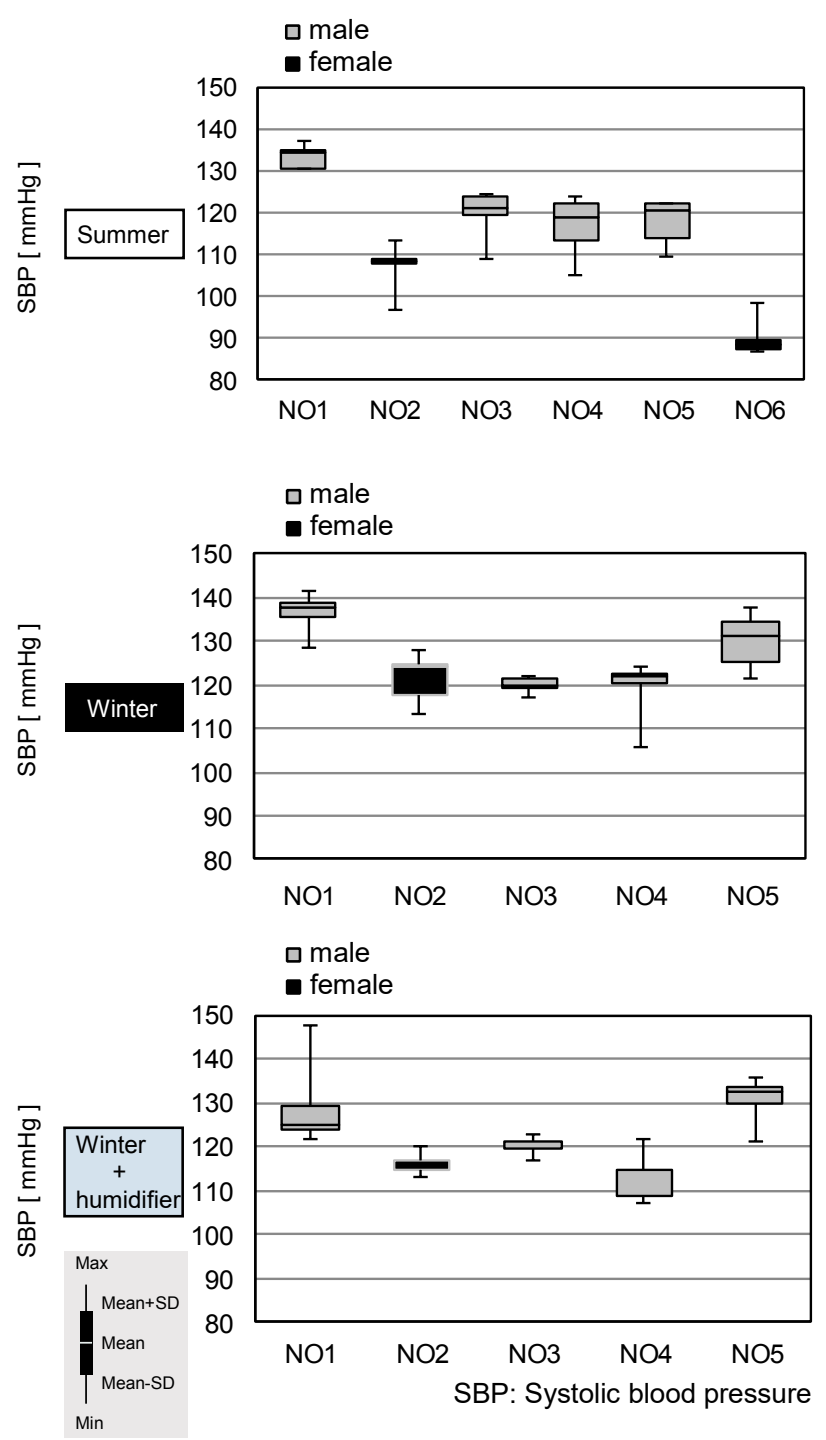

Fig. 5. Average SBP value for each condition after getting up. 
result is attributed to the influence of the whole-house air-conditioning ventilation system. Under all conditions, the sleep onset latency was short, and good sleep trends were observed.

\subsection{Skin moisture content}

Figure 4 shows the average value of the skin moisture for each condition after getting up. Regarding the improvement rate of the average skin moisture content under each condition, the skin moisture content of all participants increased with the use of a humidifier.

\subsection{Change in blood pressure}

Figure 5 depicts the maximum blood pressure (systole) for individual condition/individual pressure after getting up. Based on the blood pressure by individual condition (individual pressure) of the maximum value (systole) after getting up, blood pressure tended to increase in winter, but an improvement trend was observed when using the humidifier.

\section{Discussion}

\subsection{Comparison of the whole-house air- conditioning ventilation system and individual air-conditioning}

We examined herein the results of individual airconditioning housing obtained in FY 2015 and the influence of the bedroom environment on sleep latency. Table 6 shows the experimental outline for an individual air-conditioned housing in FY 2015.

We considered the effects of individual air-conditioning and the bedroom environment on sleep in FY 2015. Figure 6 shows a comparison of the SHRI according to air-conditioning type. A little difference in the two seasons was found: air conditioning had variations, but no significant difference. Neither condition caused difficulty in maintaining sleep.

Figure 7 illustrates the sleep latency and sleep efficiency according to the air-conditioning condition in summer and winter.

The sleep latency when using the whole-house airconditioning ventilation system was rather short in both summer and winter, and a significant difference was found between the seasons. The temperature environment of the bedroom was improved by continuous air conditioning for $24 \mathrm{~h}$. The environment was presumed to be conducive to sleeping. There are not many customs in terms of air conditioning in individual air-conditioned houses, and the bedroom must be warmed before bedtime, especially in winter [7].

The sleep efficiency was good in the individual airconditioned houses, and a significant difference was found. This result confirmed that the efficiency decreases during sleep at a constant room temperature. Performing fine temperature adjustments is necessary to

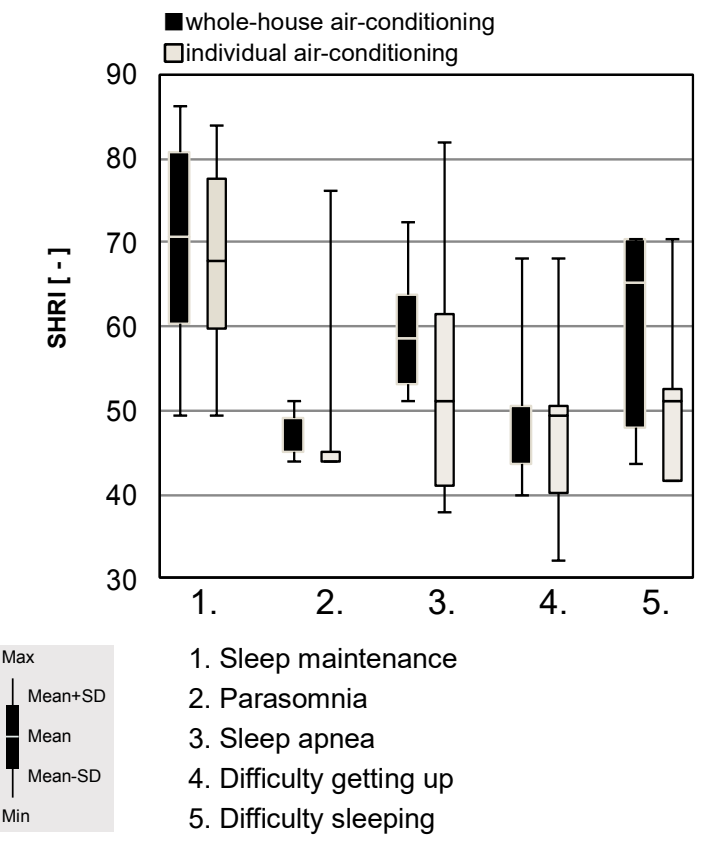

Fig. 6. Comparison of the 'Sleep Health Risk Index' (SHRI) by air-conditioning.

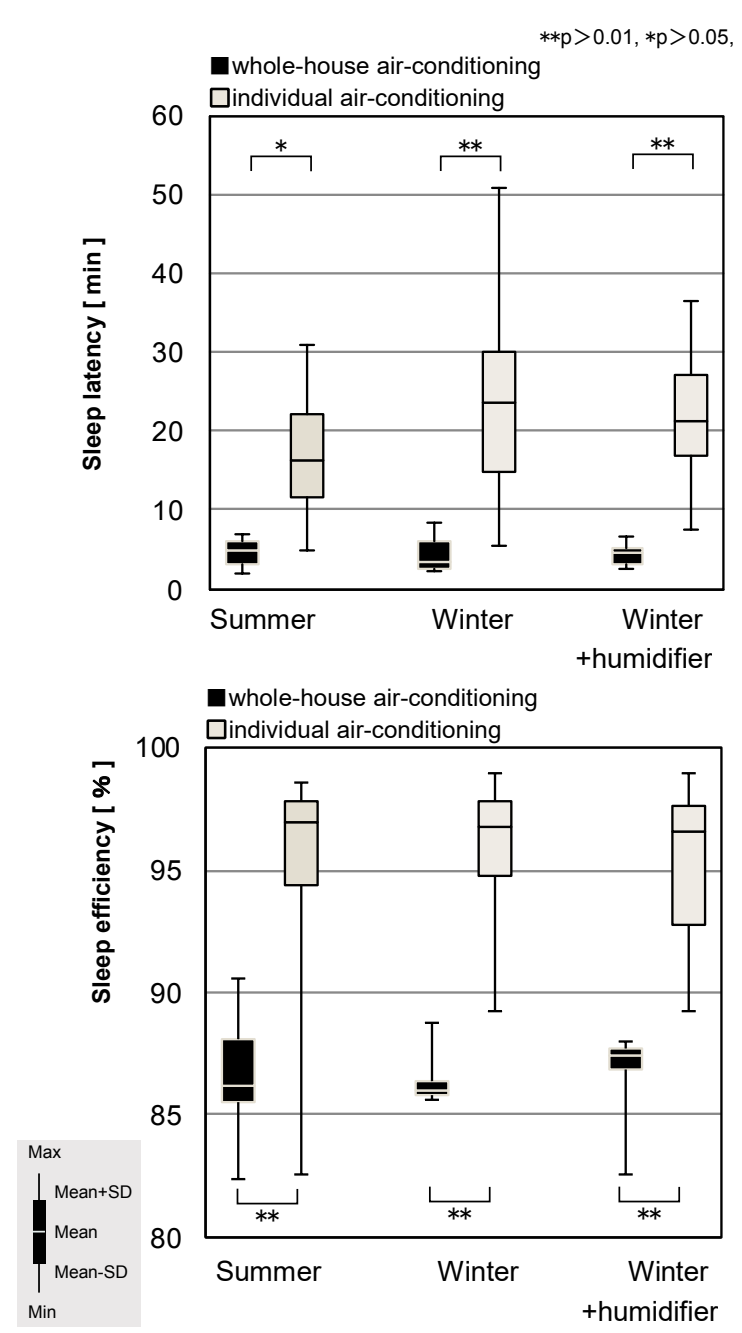

Fig. 7. Sleep latency and sleep efficiency according to the air-conditioning condition in summer and winter. 
Table 6. Average sleep measurement result of the whole-house air-conditioning ventilation system housing.

\begin{tabular}{c||c|c}
\hline Experiment location & \multicolumn{2}{|c}{ Individual air-conditioned housing / participant's bedroom } \\
\hline Measurement duration & $\begin{array}{c}\text { Summer: July 25-September 12, 2015 } \\
\text { (conditions: } 7 \text { days) }\end{array}$ & $\begin{array}{c}\text { Winter: January 5-March 5, 2016 } \\
\text { (7 days for each condition for a total of 14 days) }\end{array}$ \\
\hline Participant & $\begin{array}{c}\text { Summer: 25 middle-aged male and female } \\
\text { (37 to 58 years old) }\end{array}$ & $\begin{array}{c}\text { Winter: } 27 \text { middle-aged male and female } \\
\text { (37 to 58 years old) }\end{array}$ \\
\hline
\end{tabular}

increase the sleep efficiency [8]. The latter can be achieved by individual air-conditioning, which will be the topic of investigation in the future.

Although not shown in this section, the deep sleep appearance rate of the whole-house air-conditioning ventilation system housing was more than that of the individual air-conditioned housing, but no significant difference was observed. Figure 8 shows a comparison of the comfort levels. In the whole-house air-conditioned housing, summer and winter were extremely comfortable and only comfortable, respectively. No unpleasant answer was derived at all. Accordingly, $12 \%$ of the responses indicated a slight discomfort in the winter season for individual air-conditioned housing, which showed the greatest variation.

\section{Conclusions}

The following results were obtained from this study: (1) In the whole-house air-conditioning ventilation system housing, the sleep latency was shortened under all conditions, and the influence of the temperature adjustment before the sleep on the whole-house airconditioning ventilation system was considered. The bedroom temperature affected the good sleeping ability.

(2) The sleep efficiency was good in the individual airconditioned houses, and a significant difference was observed. This result showed that the efficiency decreases during sleep at a constant room temperature. Performing fine temperature adjustments is important in increasing the sleep efficiency. The latter can be achieved by individual air-conditioning, which will be the topic of investigation in the future.

(3) Blood pressure had the tendency to improve after getting up by using a personal humidifier, but no significant difference was observed.

(4) As for the skin moisture content, the difference in seasonal feeling was conspicuous, and the influence of the environment was considered.

(5) In subjectivity, the residents did not feel dry in the room, which resulted in high comfort of the whole-house air-conditioning ventilation system housing.

Based on the questionnaire results, the satisfaction level of the whole-house air-conditioning ventilation system housing resident is very high compared to the individual air-conditioning housing. We would like to continue this investigation in the future.

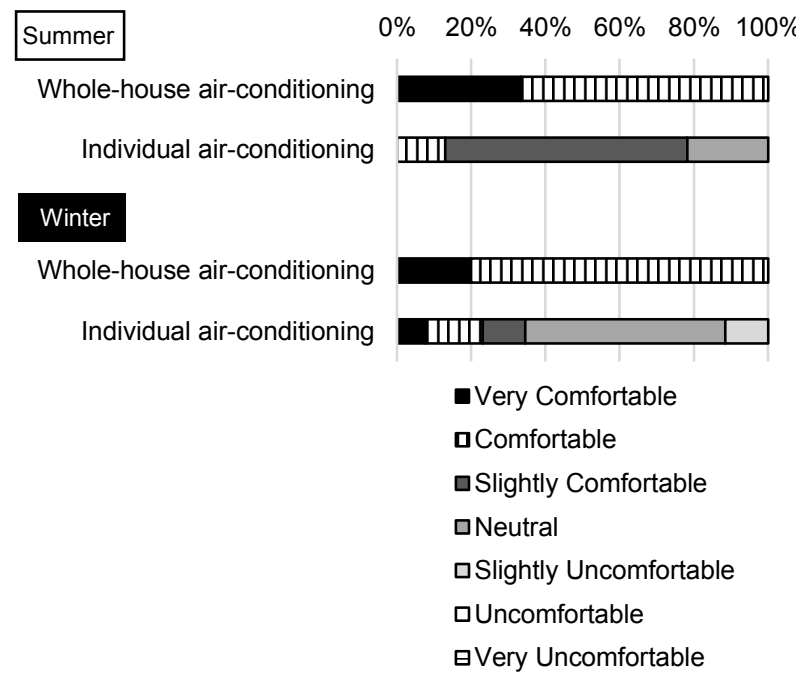

Fig. 8. Comparison of the comfort level by air conditioning.

Acknowledgment: We would like to express our gratitude to the study participants.

\section{References}

1. A. Iwaki, T. Akimoto, N. Misumi, T. Furuhashi. $J$. Human and Living Environment. 24(2) (2017)

2. H. Tanaka, S. Shirakawa. J Psychosom Res. 56 465477 (2004)

3. M. Yamamoto, T. Iga, M. Shimizu, S. Ohara, T. Urano, T. Aoki, N. Abe, F. Yoshii. Sleep Medicine. 6(3) 473-480 (2012)

4. K. Tsuzuki, K. Okamoto-Mizuno, T. Iwaki. International Journal of Biometeorology. 52(4) 261-270 (2008)

5. K. Tsuzuki. Japanese Journal of Biometeorology, 50(4) 125-134 (2014)

6. K. Okamoto-Mizuno, K. Mizuno, S. Michie, A. Maeda, S. Iizuka. Sleep. 22 767-773 (1999)

7. V.Candas, J.P.Libert, A.Muzet. Heating and cooling stimulations during SWS and REM sleep in man J.therm Biol. 7(3) 155-158 (1982)

8. A. Iwaki, T. Akimoto. COBEE2018. 504-507 (2018) 